\title{
THE ROLE OF MICRO-ORGANISMS IN THE SETTLEMENT OF OPHELIA BICORNIS SAVIGNY
}

\author{
By Douglas P. Wilson, D.Sc. \\ The Plymouth Laboratory
}

During the course of earlier work with larvae of Ophelia bicornis Savigny it became increasingly clear that a major factor in stimulating these larvae to settle and metamorphose is the presence, on sand grains of suitable size, of living micro-organisms such as bacteria, in numbers neither too many nor too few (Wilson, I954). It had been shown that an acid-cleaned sand (which is neutral or almost so) kept in sea water becomes increasingly attractive to these larvae with time. It had been admitted, however (loc. cit., p. 366), that these results were derived from a comparison of experiments not designed to this end, and that further tests, planned for the purpose, were desirable.

Methods were identical with those of 1953 (Wilson, I954), except that the relative abundance of the unmetamorphosed, metamorphosing and metamorphosed larvae in each sample as expressed in words in the tables was in I954 based on random partial counts, giving a probable slight increase in accuracy of assessment. Unmetamorphosed larvae were not counted except when sticking to a sand grain, while metamorphosing larvae were recorded as in early, mid or late metamorphosis. These stages are not usually shown in the tables but are referred to in the text wherever the stage of metamorphosis is a matter of interest.

Fertilizations and experiments were mostly in a mixture of sea water from the International Hydrographical Station EI, and from the Clyde (by kind co-operation of the Millport Marine Station). Except when otherwise stated, all sea waters were passed through Berkefeld filter candles before use. The larvae used in the tests were always 5 days old.

\section{THE EXPERIMENTS}

In preparation for the experiments some Bullhill Bank sand which had been collected on Io June I952 was thoroughly cleaned in hot concentrated sulphuric acid on 2I April I954, washed, and stored in distilled water. Such acid-cleaned sand is almost white in colour. On various dates subsequently, as noted in the description of each experiment, a quantity was removed from the distilled water, washed with filtered sea water and strewn thinly over the 
bottom of one or more covered glass dishes filled with filtered sea water. These were left on a bench shielded from direct light from the sky. The water in some dishes was changed a number of times at intervals of days or weeks; in others it was not changed. To a few dishes a little peptone sea water (Spencer, 1952, p. 98) was added from time to time to encourage bacteria. Further quantities of sand were similarly soaked for varying periods in unfiltered water from the laboratory circulation (tank water), sometimes mixed with mud from the bottoms of the tanks.

Each experiment was divided into two sections. Each section comprised a set of sands tested together in the same free-choice dish and often separately in conical vessels as well. The ability of the larvae to metamorphose was checked for each experiment by a control dish strewn with fresh Bullhill Bank sand. In these control dishes metamorphosis was invariably almost $100 \%$.

\section{Experiment I (Table I)}

Section A. Four samples of acid-cleaned sand soaked in sea water for different lengths of time and one sample soaked in tank water were tested against a sample of the same acid-cleaned sand which had been stored in distilled water throughout the experiment (see Table I for dates and other details). It will be seen from the table that the longer the sand had soaked in sea water the bigger the settlement which was obtained. These soaked sands were observed to have numbers of unidentified organisms on and among their grains. Some of the organisms were almost certainly algal; bacteria would not be seen at the magnification used. All the sands were clean, but that soaked since II June I954 (sample 4 in Table I, section A) had more 'algal' growths than the others. The sand from distilled water was perfectly clean.

Section $B$. The acid-cleaned sand samples tested here had been soaked in tank water, in one instance with the addition of tank mud, or in sea water to which peptone had been added. Some of these waters and media were changed from time to time. All the sands were discoloured by organic growths, the tank water sands being various shades of brown owing to algal growths, including diatoms. The sand from sea water with peptone medium was grey, even after washing well, and showed fluffy growths on some grains. While all these sands (after rinsing well in sea water) attracted more larvae to settle than did the sand straight from distilled water it does not appear that they were as effective as some of the cleaner sands in section A. A direct comparison with that section cannot, however, be made.

\section{Experiment 2 (Table II)}

Section A. It is known from earlier work that natural sands after washing and drying, or after sterilization in water at about $100^{\circ} \mathrm{C}$, lose any attractive property they may have had in the fresh state, and some of them become 
repellent. In this series of tests acid-cleaned sands which had become attractive after soaking in sea water for several weeks (samples 2 and 5) were likewise shown to lose their acquired attractiveness by these treatments, and one of them after treatment (sample 6) seems to have become repellent. This sand from tank water and mud (sample 5), had, before washing and drying, unidentified flocculent growths on the sand grains, which were visibly more overgrown than the grains of the sand which had been soaked in clean filtered sea water (sample 2) and which appeared to be clean, except for a few small growths seen on some grains before treatment. After treatment these had disappeared, although a few dead growths were still to be seen on the grains comprising samples 6 .

Section $B$. These tests showed that washing and drying had little or no effect on acid-cleaned sand from distilled water, so far as larval settlement is concerned, but again demonstrated that acid-cleaned sand which had acquired some degree of attractiveness by soaking in sea water lost this property after washing and drying.

Experiment 3 (Table III)

Section $A$. It was again shown that acid-cleaned sand gains in attractiveness during soaking in sea water but that this soaking has to be prolonged for several weeks to be effective. The gain after only I week (sample 2) was very slight, after 3 months (sample 3) very marked. Treatment with alcohol (sample 4) or formalin (sample 5) destroyed the attractiveness (the fixatives were well washed out first with fresh water, then with sea water), but there is no evidence that this particular sand had been made repellent by these treatments.

Section B. Fresh Bullhill Bank sand, collected a few days before the experiment began, was soaked for 4 days, 2 days and I day respectively in sea water to which peptone had been added. The peptone induced heavy growths of bacteria, especially so after 4 days, and all these sands had a pronounced smell which disappeared during rinsing in sea water before the tests were made.

From Table III it will be seen that the longer the sand had been in peptone sea water, the less attractive it was. This is even more evident if the state of the metamorphosing larvae in the conical vessels be considered. Most of those in sample 2, which had been 4 days in peptone sea water, were early and mid-metamorphosis stages, but in sample 3, which had been 2 days in peptone sea water, there was a smaller proportion of early stages and a decidedly larger proportion of late stages. In sample 4, exposed in peptone sea water for only I day, the metamorphosing larvae were almost without exception late stages.

Table III also shows that the fresh Bullhill Bank sand retained its attractiveness more effectively in sea water than when stored (in a stoppered 
jar) in its natural moist state, as collected at low tide. It is known from earlier work that the attractive property gradually diminishes when such sand is so stored.

\section{Experiment 4 (Table IV)}

Section A. Samples of acid-cleaned sand were soaked in sea water containing peptone, some of them for several weeks. One sample was kept sterile, in all the others bacterial growths took place and were heavy in those immersed for more than a day. Sample 2, which had been soaking longest with changes of the medium, was discoloured dark grey. This sand had also some flocculent brown growths, not present in the other sands which were relatively clean after rinsing before use although small organisms on the grains could be seen here and there.

The settlements obtained with these sands, after rinsing in sea water, are shown in Table IV. All (samples 2-5) attracted more larvae than the sand from sterile concentrated peptone sea water (sample I), but except for sample 3 which had soaked for Io days the settlements were not really heavy. Sample 3 produced a good settlement but the sands immersed for longer or shorter periods did not. Moreover, the metamorphosing larvae in sample 3 in the conical vessel experiment were mainly mid and late metamorphosis stages; while in all other samples, including 6 , the metamorphosing larvae had a higher proportion of early stages and a smaller proportion of late. From this it would seem that acid-cleaned sand in peptone sea water increases in attractiveness for a time and then decreases (but compare Expt. 5 B). This result should also be compared with that obtained for fresh Bullhill Bank sand (Expt. 3 B) kept in peptone sea water; only a decrease in attractiveness was then recorded.

Another portion of sand from sample 2 was washed in tap water and sterilized by heating almost to boiling-point (sample 6). The attractiveness was less than the sand not so treated, but it did not become repellent. The sand grains were cleaner than the unsterilized grains in sample 2, in particular the flocculent growths were no longer visible. In the conical vessel test of this sand most of the metamorphosing larvae were relatively early stages, there being very few late stages and a smaller proportion than in sample 2 .

Section $B$. The four sand samples tested here comprised two distinct and unrelated tests. In the first test an acid-cleaned sand soaked in sea water for about a month (Table IVB, sample I) was compared with a similar acidcleaned sand soaked in sea water plus 'B.B. water' (see Wilson, I954, p. 363) for over a year (sample 2). The latter sand had been used in the I953 series of experiments, but had been kept since then with only a single addition of fresh filtered sea water, in March 1954. Both these sands, compared with the control sample 4 from distilled water, were attractive to the larvae but that which had been soaked for a year was much more attractive than that which 
had been in sea water for only a month. This year-old sand was seen to have minute diatoms, other algae, a few flagellates, and apparently bacterial slimes on the grains, whereas the other sands were clean. It was not as dirty, however, as sample 2 in section A of this experiment, and was not noticeably discoloured.

The second comparison was between an acid-cleaned sand (sample 4) and similar sand (sample 3) which had been enclosed within a bolting silk envelope and buried in Salthouse Lake (Station II) sand which had previously been heated in tap water near to boiling point to ensure maximum repellence. The test was to determine if any part of the repellent property of a repellent sand can be transferred to a neutral sand in close proximity though not in contact with it. Some earlier experiments had indicated that such transference, if it occurs at all, takes place more readily when physical contact between grains is allowed (Expt. 43, Wilson, I953a) and doubtfully so when the two sands are separated by bolting silk (Wilson, 1953b). But in these earlier experiments the sands used were fresh and unsterilized, and the attractive factor would therefore be present as well. In the present test this would not be so. The result (Table IVB) gives no indication that any part of the repellent factor was transferred. In the free-choice dish no significant difference was discernible, while comparison of the conical vessel tests suggests that sample 3 was a little more attractive than the control (sample 4). This result is explicable if it be assumed that the repellent factor consists of organic matter, which after heating is too adherent to the grains to be passed through the meshes of bolting silk. Bacteria would be able to pass through the meshes, and it is possible that the neutral sand within the silk envelope would receive bacteria from those that would multiply on this organic matter after the heated sand, heaped around the silk envelope, had been in sea water for a short time. Thus the neutral sand after receiving adherent living bacteria, and perhaps other organisms, would be slightly attractive.

\section{Experiment $5($ Table $V)$}

Section A. This was a repetition of Expt. 3 B after the sands had been kept for another 6 days. The result (see Table V) was much as before, no further marked decrease in attractiveness of the originally fresh Bullhill Bank sand having taken place, perhaps because the grains in the earlier experiment already carried as many micro-organisms as could be accommodated on their surfaces. However, the metamorphosing larvae in sample 4 from the conical vessel were not almost all late stages as they had been in the corresponding sample in Expt. 3B, and in general there was detectable a further slight decline in attractiveness.

Section B. Some of the acid cleaned sands tested in Expt. $4 \mathrm{~A}$ after immersion for varying periods in peptone sea water (medium not changed) were re-tested after a further period had elapsed. The result (Table VB) is much as 
before (Table IVA), there not being any definite increase in attractiveness of sample 3 , and especially sample 4 , such as might have been expected. Sample 2 was, as before, more attractive than either. These results indicate that acidcleaned sand kept in peptone sea water does not necessarily show a regular increase in attractiveness with time when kept in this medium, as seemed to be implied by Expt. IVA. It is not known if the organisms encouraged by the peptone were the same species for all samples and the observed difference in settlement between the various sand samples could relate to a specific difference between the organisms grown, or to their proportional abundance. It may be noted that all sands looked nearly quite clean, only a few unidentified growths being noted on some grains. The sand of sample 4 definitely had fewer visible growths on the grains than did samples 2 and 3 . No such growths were seen on any grains from sample $\mathrm{I}$.

\section{Discussion}

A consideration of the 1954 experiments taken in conjunction with those of previous years makes it clear that the factor most active in inducing settlement of Ophelia bicornis larvae is the presence, on the sand grains, of living micro-organisms. The organisms must be neither too few nor too abundant. Presumably for a sand to attain maximum attractiveness they must be of particular species in certain relative abundance. In the experiments in which acidcleaned sands were soaked in filtered sea water it is most unlikely that the latter requirements were even approximately fulfilled; indeed it seems probable that the species of organisms which grew under those conditions were mostly not the same and were not in the same relative abundance as those present on sand grains freshly gathered from the surface of the Bullhill Bank. None the less, after several weeks of soaking in sea water, they did impart a very considerable degree of attractiveness to acid-cleaned sand. No other explanation of the observed results seems possible.

The period needed to impart a marked attractiveness to acid-cleaned grains was very considerably shortened by adding peptone sea water to the filtered sea water in which they were immersed, but this never made the sand as attractive as did some of the prolonged soakings in filtered sea water without the addition of nutrients. Presumably the grains after immersion in the peptone sea water would become coated with micro-organisms different from those that grew slowly in pure filtered sea water, and they may well have become too abundant to attract very many larvae.

It was observed that fresh Bullhill Bank sand after immersion in peptone sea water became less attractive than before, especially after a heavy growth of bacteria had taken place. These observations support the conclusion that the quantity and quality of the living organic film on the grain surface is of first rate importance to the settling Ophelia larva. To the identity of the species concerned and their actual abundance there is at present no clue. 
This series of studies has been another demonstration of the influence of the minutest micro-flora and fauna on the distribution and activities of larger microscopic animals and ultimately on the macro-fauna itself. They suggest that more attention could profitably be paid to the most minute living constituents of bottom deposits and their interrelations with the larger organisms subsisting in or on those soils.

The organic films left on natural sand grains after washing and drying are undoubtedly to a large extent responsible for the floatation properties of dried grains, discussed in previous papers (see especially Wilson, I952). Less than one per cent of acid-cleaned grains stored in distilled water float when sprinkled dry on the surface of water, but during the course of the experiments recorded in this paper it was found that after some days of immersion in sea water a markedly higher percentage floated (after washing and drying). After several weeks or months the percentage of floatable grains was still higher and in one instance was over $90 \%$. The percentage floatability of acid-cleaned sand rose steeply and more quickly during immersion in peptone sea water, and the floatation of fresh Bullhill Bank sand was also raised by immersion in peptone sea water. That flotation can be caused by electrical charges produced on the grains by rubbing is probably also true, but is likely to have little bearing on problems concerned with settlement reactions.

It seems certain that dead organic matter coating sand grains is repellent to Ophelia bicornis larvae and renders many sands such as Salthouse Lake sand (Stations I and II), after the silt has been washed away, distasteful to these larvae. The repellent effect is likely to be most marked if there are no living micro-organisms present as well, as when sands have been sterilized in water at $100^{\circ} \mathrm{C}$, or after fixation or drying. Sands will thus vary in attractiveness and repellence according to the number and kinds of living micro-organisms, and according to the amount and quality of the non-living organic materials coating the grains. Grain size, and perhaps also shape, is another and lesser factor influencing larvae about to settle, but is not the main factor as was earlier thought (Wilson, I948). That grade does exert some influence has often been demonstrated (Wilson, $1953 b$ ).

\section{SUMMARY}

Experiments in the summer of 1954 made it clear that the factor most active in inducing metamorphosis and settlement of Ophelia bicornis Savigny larvae is the presence on sand grains of living micro-organisms, such as bacteria, and that these should be neither too few nor too abundant. It would appear likely, and for this there is some evidence, that certain species are more effective in promoting settlement than are others, though there is at present no clue to the identities of the species concerned. Dead organisms and non-living organic matter are not attractive and may indeed be repellent, as a consideration of some of the results suggests. 


\section{REFERENCES}

SPENCER, C. P., I952. On the use of antibiotics for isolating bacteria-free cultures of marine phytoplankton organisms. F. Mar. biol. Ass. U.K., Vol. 3I, pp. 97Io6.

WILsON, D. P., I948. The relation of the substratum to the metamorphosis of Ophelia larvae. F. Mar. biol. Ass. U.K., Vol. 27, pp. 723-60.

- 1952. The influence of the nature of the substratum on the metamorphosis of the larvae of marine animals, especially the larvae of Ophelia bicornis Savigny. Ann. Inst. océanogr. Monaco., T. 27, pp. 49-156.

- I953 $a$. The settlement of Ophelia bicornis Savigny larvae. The I95I experiments. F. Mar. biol. Ass. U.K., Vol. 31, pp. 413-38.

- I953 $b$. The settlement of Ophelia bicornis Savigny larvae. The 1952 experiments. F. Mar. biol. Ass. U.K., Vol. 32, pp. 209-33.

- 1954. The attractive factor in the settlement of Ophelia bicornis Savigny. F. Mar. biol. Ass. U.K., Vol. 33, pp. 36I-80. 


\section{TABle I. EXPERIMENT I}

Begun 5. vii. 54 with larvae 5 days old. Results on 7. vii. 54

Section A

Acid-cleaned Bullhill Bank sand soaked in

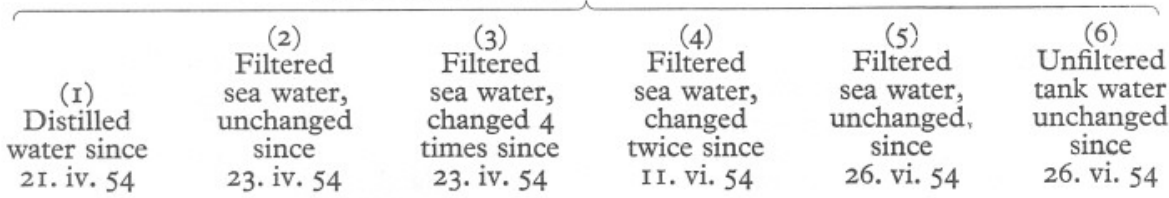

Settlements after 2 days in free-choice dish

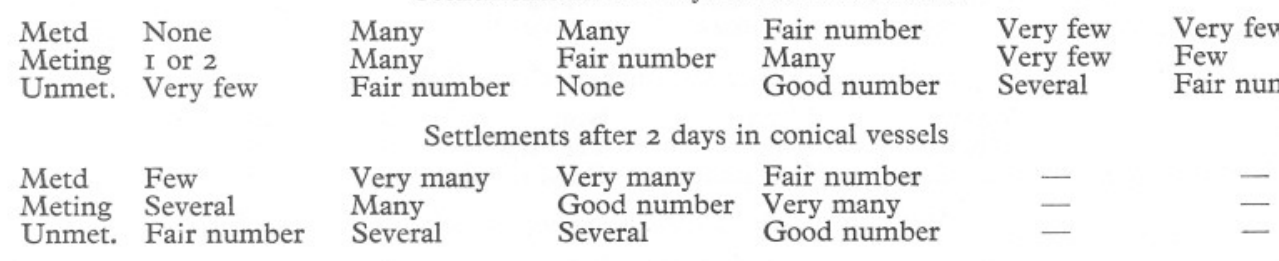

Section B

Acid-cleaned Bullhill Bank sand soaked in

\begin{tabular}{|c|c|c|c|c|}
\hline & $\begin{array}{c}\text { (2) } \\
\text { Unfiltered } \\
\text { tank water, } \\
\text { changed } 4\end{array}$ & $\begin{array}{c}\text { (3) } \\
\text { Unfiltered } \\
\text { tank water, } \\
\text { unchanged }\end{array}$ & $\begin{array}{c}\text { (4) } \\
\text { Unfiltered } \\
\text { tank water and } \\
\text { mud, changed }\end{array}$ & $\begin{array}{l}\text { (5) } \\
\text { Filtered sea } \\
\text { water containing } \\
\text { peptone, changed } \\
\text { 3 times since }\end{array}$ \\
\hline $\begin{array}{l}\text { ater since } \\
2 \text { I. iv. } 54\end{array}$ & $\begin{array}{c}\text { 23. iv. } 54 \\
\text { (sand dark brown) }\end{array}$ & $\begin{array}{c}23 . \text { iv. } 54 \\
\text { (sand pale brown) }\end{array}$ & $\begin{array}{l}\text { 23. iv. } 54 \\
\text { (sand brown) }\end{array}$ & $\begin{array}{l}\text { 23. iv. } 54 \\
\text { (sand grey) }\end{array}$ \\
\hline
\end{tabular}

Settlements after 2 days in free-choice dish

\begin{tabular}{|c|c|c|c|c|c|}
\hline Metd & None & Few & Fair number & Fair number & Several \\
\hline Meting & Very few & Several & Several & Few & Several \\
\hline net. & Several & Good number & Good number & Several & Fair number \\
\hline
\end{tabular}

Settlements after 2 days in conical vessels

$\begin{array}{lcllll}\text { Metd } & \text { See A I above } & \text { Very few } & \text { Several } & \text { Good number } & \text { Many } \\ \text { Meting } & - & \text { Few } & \text { Fair number } & \text { Fair number } & \text { Many } \\ \text { Unmet. } & - & \text { Several } & \text { Many } & \text { Several } & \text { Few }\end{array}$

Metd $=$ metamorphosed meting = metamorphosing; unmet. $=$ unmetamorphosed.

Scale of words used to express number in Tables I-V:

$\begin{array}{ll}\text { Very few (sometimes also expressed in numbers I-4) } & \text { Many } \\ \text { Few } & \text { Very many } \\ \text { Several } & \text { Multitude } \\ \text { Fair number } & \text { Great multitude } \\ \text { Good number } & \end{array}$




\section{TABLE II. EXPERIMENT 2}

Begun IO. vii. 54 with larvae 5 days old. Results on I2. vii. 54

Section A

Acid-cleaned Bullhill Bank sand soaked in

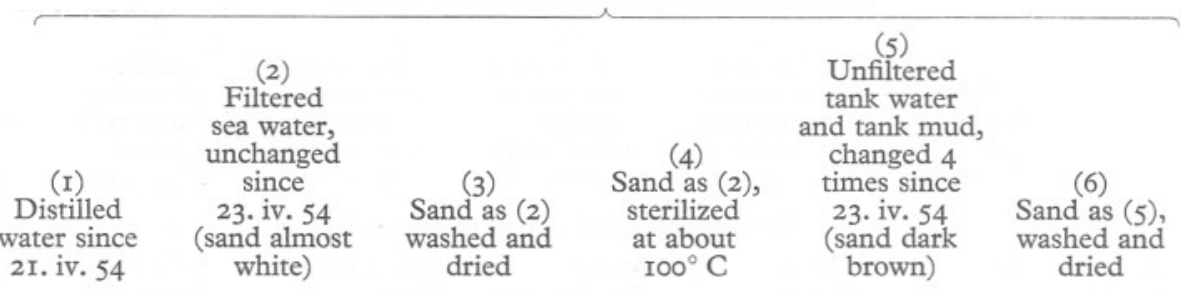

Settlements after 2 days in free-choice dish

\begin{tabular}{|c|c|c|c|c|c|c|}
\hline Metd & None & Many & None & None & Good number & None \\
\hline Meting & None & Many & None & Very few & Good number & None \\
\hline Unmet. & Fair number & Several & Fair number & Good number & Fair number & Very few \\
\hline \multicolumn{7}{|c|}{ Settlements after 2 days in conical vessels } \\
\hline Metd & Very few & Many & Very few & Few & Many & None \\
\hline Meting & Few & Many & Few & Very few & Fair number & None \\
\hline Unmet. & Fair number & Fair number & Fair number & Fair number & Fair number & Very few \\
\hline
\end{tabular}

\begin{tabular}{|c|c|c|c|c|}
\hline & $\begin{array}{l}\text { (I) } \\
\text { Acid-cleaned } \\
\text { Bullhill Bank } \\
\text { sand in distilled } \\
\text { water since } \\
\text { 2I. iv. } 54\end{array}$ & $\begin{array}{l}\text { (2) } \\
\text { Sand as (I), } \\
\text { washed and dried }\end{array}$ & $\begin{array}{l}\text { (3) } \\
\text { Sand as (I) } \\
\text { in filtered } \\
\text { sea water, } \\
\text { unchanged since } \\
\text { 26. vi. } 54\end{array}$ & $\begin{array}{c}\text { (4) } \\
\text { Sand as (3), } \\
\text { washed and dried }\end{array}$ \\
\hline \multicolumn{5}{|c|}{ Settlement after 2 days in free-choice dish } \\
\hline $\begin{array}{l}\text { Metd } \\
\text { Meting } \\
\text { Unmet. }\end{array}$ & $\begin{array}{l}\text { None } \\
\text { None } \\
\text { Fair number }\end{array}$ & $\begin{array}{l}\text { One } \\
\text { One } \\
\text { Fair number }\end{array}$ & $\begin{array}{l}\text { Several } \\
\text { Several } \\
\text { Fair number }\end{array}$ & $\begin{array}{l}\text { None } \\
\text { None } \\
\text { Several }\end{array}$ \\
\hline \multicolumn{5}{|c|}{ Settlements after 2 days in conical vessels } \\
\hline $\begin{array}{l}\text { Metd } \\
\text { Meting }\end{array}$ & See A I above & $\begin{array}{l}\text { None } \\
\text { Several }\end{array}$ & $\begin{array}{l}\text { Several } \\
\text { Several (early } \\
\text { to late) }\end{array}$ & $\begin{array}{l}\text { None } \\
\text { Several (all early) }\end{array}$ \\
\hline Unmet. & - & Fair number & Fair number & Fair number \\
\hline
\end{tabular}




\section{TABLE III. EXPERIMENT 3}

Begun 2I. vii. 54 with larvae 5 days old. Results on 23. vii. 54

Section A

Acid-cleaned Bullhill Bank sand soaked in

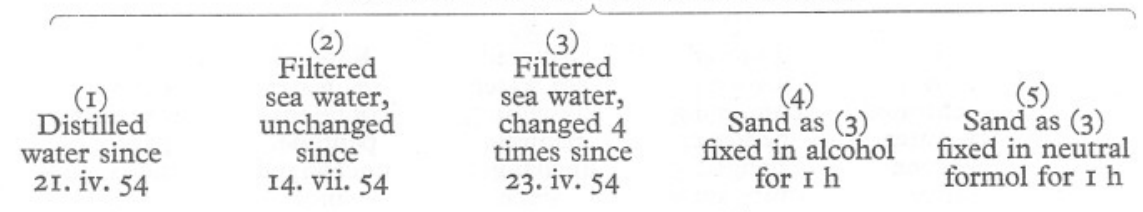

Settlements after 2 days in free-choice dish

\begin{tabular}{|c|c|c|c|c|c|}
\hline $\begin{array}{l}\text { Metd } \\
\text { Meting } \\
\text { Unmet. }\end{array}$ & $\begin{array}{l}\text { None } \\
\text { None } \\
\text { Fair number }\end{array}$ & $\begin{array}{l}\text { None } \\
\text { Very few } \\
\text { Good number }\end{array}$ & $\begin{array}{l}\text { Many } \\
\text { Many } \\
\text { Fair number }\end{array}$ & $\begin{array}{l}\text { Very few } \\
\text { Very few } \\
\text { Good number }\end{array}$ & $\begin{array}{l}\text { None } \\
\text { Very few } \\
\text { Several }\end{array}$ \\
\hline \multicolumn{6}{|c|}{ Settlements after 2 days in conical vessels } \\
\hline $\begin{array}{l}\text { Metd } \\
\text { Meting } \\
\text { Unmet. }\end{array}$ & $\begin{array}{l}\text { Very few } \\
\text { Fair number } \\
\text { Many }\end{array}$ & $\begin{array}{l}\text { Several } \\
\text { Several } \\
\text { Many }\end{array}$ & $\begin{array}{l}\text { Very many } \\
\text { Good number } \\
\text { Several }\end{array}$ & $\begin{array}{l}\text { None } \\
\text { Fair number } \\
\text { Many }\end{array}$ & $\begin{array}{l}\text { Few } \\
\text { Many } \\
\text { Fair number }\end{array}$ \\
\hline
\end{tabular}

Section B

Fresh Bullhill Bank sand (collected 15. vii. 54) soaked in

\begin{tabular}{|c|c|c|c|c|}
\hline $\begin{array}{l}(\mathrm{I}) \\
\text { Filtered } \\
\text { sea water } \\
\text { since } \\
\text { I7. vii. } 54\end{array}$ & $\begin{array}{l}(2) \\
\text { Filtered } \\
\text { sea water } \\
\text { containing } \\
\text { peptone, } \\
\text { unchanged } \\
\text { since } \\
\text { 17. vii. } 54\end{array}$ & $\begin{array}{l}\text { (3) } \\
\text { Filtered } \\
\text { sea water } \\
\text { containing } \\
\text { peptone, } \\
\text { unchanged } \\
\text { since } \\
\text { I9. vii. } 54\end{array}$ & $\begin{array}{l}(4) \\
\text { Filtered } \\
\text { sea water } \\
\text { containing } \\
\text { peptone, } \\
\text { unchanged } \\
\text { since } \\
\text { 20. vii. } 54\end{array}$ & $\begin{array}{l}\text { Fresh Bullhill } \\
\text { Bank sand kept } \\
\text { in natural moist } \\
\text { state since } \\
\text { I5. vii. } 54\end{array}$ \\
\hline \multicolumn{5}{|c|}{ Settlements after 2 days in free-choice dish } \\
\hline $\begin{array}{l}\text { ltitude } \\
\text { od number } \\
\text { reral }\end{array}$ & $\begin{array}{l}\text { Few } \\
\text { Few } \\
\text { Few }\end{array}$ & $\begin{array}{l}\text { Very few } \\
\text { Fair number } \\
\text { Several }\end{array}$ & $\begin{array}{l}\text { Several } \\
\text { Many } \\
\text { Fair number }\end{array}$ & $\begin{array}{l}\text { Very many } \\
\text { Fair number } \\
\text { Few }\end{array}$ \\
\hline \multicolumn{5}{|c|}{ Settlements after 2 days in conical vessels } \\
\hline $\begin{array}{l}\text { eat multitude } \\
\text { ry few } \\
\text { ne }\end{array}$ & $\begin{array}{l}\text { Several } \\
\text { Multitude } \\
\text { Good numl }\end{array}$ & $\begin{array}{l}\text { Good number } \\
\text { Great multitude } \\
\text { Very few }\end{array}$ & $\begin{array}{l}\text { Multitude } \\
\text { Multitude } \\
\text { None }\end{array}$ & $\begin{array}{l}\text { Great } \\
\text { Few } \\
\text { None }\end{array}$ \\
\hline
\end{tabular}




\section{TABle IV. Experiment 4}

Begun 24. vii. 54 with larvae 5 days old. Results on 26. vii. 54

Section A

Acid-cleaned Bullhill Bank sand soaked in

\begin{tabular}{|c|c|c|c|c|c|}
\hline & (2) & (3) & (4) & (5) & \\
\hline (I) & Filtered & Filtered & Filtered & Filtered & (6) \\
\hline Sterile & sea water & sea water & sea water & sea water & Sand as (2) \\
\hline concentrated & containing & containing & containing & containing & washed in \\
\hline $\begin{array}{l}\text { sea water } \\
\text { peptone } \\
\text { since }\end{array}$ & $\begin{array}{l}\text { peptone, } \\
\text { changed } 5 \\
\text { times since }\end{array}$ & $\begin{array}{l}\text { peptone, } \\
\text { unchanged } \\
\text { since }\end{array}$ & $\begin{array}{l}\text { peptone, } \\
\text { unchanged } \\
\text { since }\end{array}$ & $\begin{array}{l}\text { peptone, } \\
\text { unchanged } \\
\text { since }\end{array}$ & $\begin{array}{c}\text { tap water } \\
\text { and sterilized } \\
\text { at about }\end{array}$ \\
\hline I. V. 54 & 23. iv. 54 & I4. vii. 54 & 2I. vii. 54 & 23. vii. 54 & $100^{\circ} \mathrm{C}$ \\
\hline
\end{tabular}

Settlements after 2 days in free-choice dish

\section{Metd None \\ Meting Several \\ Unmet. Fair number}

Very few

Fair number

Fair number Very few

Good number Few

Good number Fair number
Fair number

Very few

Several

Fair number

Very few

Few

Fair number

Settlements after 2 days in conical vessels

$\begin{array}{lll}\text { Many } & \text { None } & \text { Few } \\ \text { Very many } & \text { Very many } & \text { Very many } \\ \text { Fair number } & \text { Very many } & \text { Many }\end{array}$

Very few Good number Fair number

Section B

Acid-cleaned Bullhill Bank sand

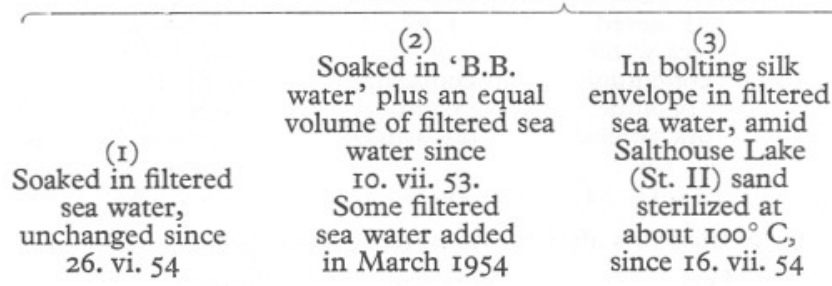

Settlements after 2 days in free-choice dish

\begin{tabular}{|c|c|c|c|c|}
\hline Metd & Fair number & Many & Very few & Very few \\
\hline Meting & Fair number & Good number & Very few & Very few \\
\hline Unmet. & Fair number & Many & Several & Fair number \\
\hline \multicolumn{5}{|c|}{ Settlements after 2 days in conical vessels } \\
\hline Metd & Fair number & Multitude & Fair number & None \\
\hline Meting & Good number & Multitude & Fair number & Fair number \\
\hline Unmet. & Very many & Many & Fair number & Fair number \\
\hline
\end{tabular}




\section{TABLE V. EXPERIMENT 5}

Begun 27. vii. 54 with larvae 5 days old. Results on 29. vii. 54

Section A

Fresh Bullhill Bank sand (collected I5. vii. 54) soaked in

\begin{tabular}{|c|c|c|c|c|}
\hline (I) & $\begin{array}{c}(2) \\
\text { Filtered } \\
\text { sea water }\end{array}$ & $\begin{array}{c}\text { (3) } \\
\text { Filtered } \\
\text { sea water }\end{array}$ & $\begin{array}{c}(4) \\
\text { Filtered } \\
\text { sea water }\end{array}$ & (5) \\
\hline Filtered & containing & containing & containing & Fresh Bullhill \\
\hline sea water & peptone, & peptone, & peptone, & Bank sand kept \\
\hline $\begin{array}{l}\text { unchanged } \\
\text { since }\end{array}$ & $\begin{array}{l}\text { unchanged } \\
\text { since }\end{array}$ & $\begin{array}{l}\text { unchanged } \\
\text { since }\end{array}$ & $\begin{array}{l}\text { unchanged } \\
\text { since }\end{array}$ & $\begin{array}{l}\text { in natural moist } \\
\text { state since }\end{array}$ \\
\hline I7. vii. 54 & I7. vii. 54 & I9. vii. 54 & 20. vii. 54 & I5. vii. 54 \\
\hline
\end{tabular}

Settlements after 2 days in free-choice dish

\begin{tabular}{|c|c|c|c|c|}
\hline $\begin{array}{l}\text { Metd } \\
\text { Meting }\end{array}$ & $\begin{array}{l}\text { Very many } \\
\text { Fair number }\end{array}$ & $\begin{array}{l}\text { Several } \\
\text { Several }\end{array}$ & $\begin{array}{l}\text { Few } \\
\text { Few }\end{array}$ & $\begin{array}{l}\text { Fair number } \\
\text { Good number }\end{array}$ \\
\hline & Very few & Few & Several & Fair number \\
\hline
\end{tabular}

Settlements after 2 days in conical vessels

$\begin{array}{llllll}\text { Metd } & \text { Great multitude } & \text { Fair number } & \text { Fair number } & \text { Very many } & \text { Great multitude } \\ \text { Meting } & \text { Few } & \text { Many } & \text { Very many } & \text { Very many } & \text { Fair number } \\ \text { Unmet. } & \text { None } & \text { Very few } & \text { Very few } & \text { Very few } & \text { None }\end{array}$

Section B

Acid-cleaned Bullhill Bank sand soaked in

$\begin{array}{cccc}\begin{array}{c}\text { (I) } \\ \text { Distilled }\end{array} & \begin{array}{c}\text { Filtered sea water } \\ \text { containing peptone, } \\ \text { unchanged since }\end{array} & \begin{array}{c}\text { Filtered sea water } \\ \text { containing peptone, } \\ \text { unchanged since }\end{array} & \begin{array}{c}\text { Filtered sea water } \\ \text { containing peptone, } \\ \text { unchanged since }\end{array} \\ \text { 2I. vi. } 54 & \begin{array}{c}\text { I4. vii. } 54 \\ \text { 2I. vii. } 54\end{array} & \text { 23. vii. } 54\end{array}$

Settlements after 2 days in free-choice dish

$\begin{array}{lllll}\text { Metd } & \text { Few } & \text { Fair number } & \text { Very few } & \text { None } \\ \text { Meting } & \text { Few } & \text { Fair number } & \text { Several } & \text { Few } \\ \text { Unmet. } & \text { Fair number } & \text { Good number } & \text { Good number } & \text { Fair number }\end{array}$

Settlements after 2 days in conical vessels

$\begin{array}{lllll}\text { Metd } & \text { Several } & \text { Multitude } & \text { Very many } & \text { Several } \\ \text { Meting } & \text { Several } & \text { Multitude } & \text { Many } & \text { Multitude } \\ \text { Unmet. } & \text { Very many } & \text { Few } & \text { Good number } & \text { Very many }\end{array}$

